\title{
Prospects of e-beam evaporated molybdenum oxide as a hole transport layer for perovskite solar cells
}

Cite as: J. Appl. Phys. 122, 123105 (2017); https://doi.org/10.1063/1.4996784

Submitted: 19 July 2017 . Accepted: 08 September 2017 . Published Online: 25 September 2017

F. Ali, (D) N. Khoshsirat, J. L. Duffin, H. Wang, K. Ostrikov, J. M. Bell, and (D) T. Tesfamichael

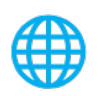

\section{ARTICLES YOU MAY BE INTERESTED IN}

Effective hole extraction using $\mathrm{MoO}_{\mathbf{x}}-\mathrm{Al}$ contact in perovskite $\mathrm{CH}_{3} \mathrm{NH}_{3} \mathrm{~Pb} / 3$ solar cells

Applied Physics Letters 104, 213906 (2014); https://doi.org/10.1063/1.4880899

Unusual defect physics in $\mathrm{CH}_{3} \mathrm{NH}_{3} \mathrm{~Pb} \mathrm{Pl}_{3}$ perovskite solar cell absorber

Applied Physics Letters 104, 063903 (2014); https://doi.org/10.1063/1.4864778

Detailed Balance Limit of Efficiency of p-n Junction Solar Cells

Journal of Applied Physics 32, 510 (1961); https://doi.org/10.1063/1.1736034

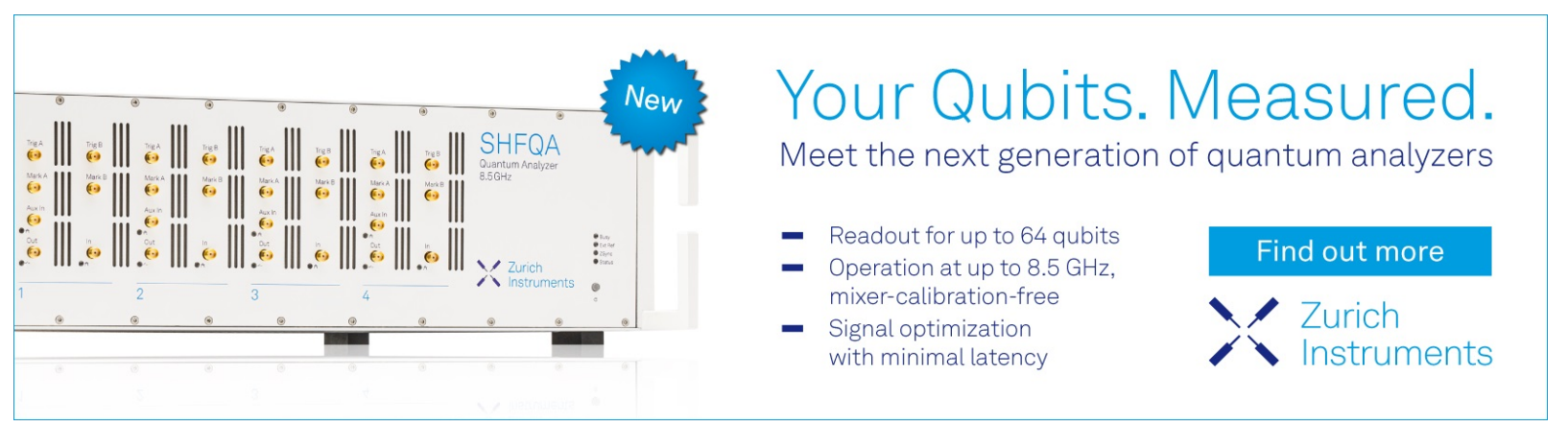




\title{
Prospects of e-beam evaporated molybdenum oxide as a hole transport layer for perovskite solar cells
}

\author{
F. Ali, N. Khoshsirat, J. L. Duffin, H. Wang, K. Ostrikov, J. M. Bell, and T. Tesfamichael ${ }^{\text {a) }}$ \\ School of Chemistry, Physics and Mechanical Engineering, Science and Engineering Faculty, Queensland \\ University of Technology, 2 George Street, Brisbane, 4000 QLD, Australia
}

(Received 19 July 2017; accepted 8 September 2017; published online 25 September 2017)

\begin{abstract}
Perovskite solar cells have emerged as one of the most efficient and low cost technologies for delivering of solar electricity due to their exceptional optical and electrical properties. Commercialization of the perovskite solar cells is, however, limited because of the higher cost and environmentally sensitive organic hole transport materials such as spiro-OMETAD and PEDOT:PSS. In this study, an empirical simulation was performed using the Solar Cell Capacitance Simulator software to explore the $\mathrm{MoO}_{\mathrm{x}}$ thin film as an alternative hole transport material for perovskite solar cells. In the simulation, properties of $\mathrm{MoO}_{\mathrm{x}}$ thin films deposited by the electron beam evaporation technique from high purity (99.99\%) $\mathrm{MoO}_{3}$ pellets at different substrate temperatures (room temperature, $100^{\circ} \mathrm{C}$ and $200^{\circ} \mathrm{C}$ ) were used as input parameters. The films were highly transparent $(>80 \%)$ and have low surface roughness $(\leq 2 \mathrm{~nm})$ with bandgap energy ranging between $3.75 \mathrm{eV}$ and $3.45 \mathrm{eV}$. Device simulation has shown that the $\mathrm{MoO}_{\mathrm{x}}$ deposited at room temperature can work in both the regular and inverted structures of the perovskite solar cell with a promising efficiency of $18.25 \%$. Manufacturing of the full device is planned in order to utilize the $\mathrm{MoO}_{\mathrm{x}}$ as an alternative hole transport material for improved performance, good stability, and low cost of the perovskite solar cell. Published by AIP Publishing.
\end{abstract}

[http://dx.doi.org/10.1063/1.4996784]

\section{INTRODUCTION}

Perovskite solar cells (PSCs) are one of the promising technologies in photovoltaics that have encouraged the world's ambition towards solar energy utilization at low cost. Due to the low cost and simple solution procedure, PSCs have revolutionized the field of photovoltaic research. The efficiency of PSC has increased from $3.8 \%{ }^{1}$ in 2009 to more than $20 \%$ in $2016 .{ }^{2}$ Despite the high efficiency of the solar cell, the hole transport materials (HTM) used are mostly limited to organic compounds including $2,2^{\prime}, 7,7^{\prime}$ tetrakis(N,N-di-p-methoxyphenylamine)-9,9'-spirobifluorene (spiro-OMeTAD) ${ }^{3}$ and poly(3,4-ethylenedioxythiophene) polystyrene sulfonate (PEDOT:PSS). These materials are expensive and have poor stability upon exposure to the environment. ${ }^{4,5}$ The acidic nature of PEDOT:PSS ${ }^{6}$ and the hygroscopic nature of the additives used in the spiro-OMeTAD decreases the long term stability of PSCs. ${ }^{7}$ In practice, high cost and poor environmental stability are the main limitations for large scale applications of the PSCs. Metal oxides will be a better replacement to overcome these challenges. Metal oxide thin films have been widely used in various applications such as display devices, optical small window, gas sensors, and photovoltaics ${ }^{8}$ and they can be a better candidate as HTM for solar cells. ${ }^{9,10}$ Inorganic hole transport materials such as $\mathrm{NiO}, \mathrm{Cu}_{2} \mathrm{O}, \mathrm{CuO}_{\mathrm{x}}$, and $\mathrm{VO}_{\mathrm{x}}$ have been incorporated into PSC as a replacement of the existing organic $\mathrm{HTMs}^{4,11}$ due to their higher stability and lower materials cost than organic materials. ${ }^{12} \mathrm{MoO}_{\mathrm{x}}$ is one of the potential materials

\footnotetext{
a) Author to whom correspondence should be addressed: t.tesfamichael@qut. edu.au. Tel.: +61-7-31381988. Fax: +61-7-31381516.
}

not only for solar cells but also gas sensors and light-emitting diodes. ${ }^{13}$ Recently, $\mathrm{MoO}_{2}$ nanoparticles were used as a hole transport layer with efficiency of $15 \%$, with very low hysteresis and high device stability. ${ }^{14}$ Similarly, $\mathrm{MoO}_{\mathrm{x}}$ has been used as a hole selective contact for silicon solar cell. ${ }^{15}$ Xiao et al. use $\mathrm{MoO}_{\mathrm{x}}$ as a hole transport layer for perovskite solar cells but only achieved low efficiency of 5.9\%. ${ }^{16}$ Hou et al. used bilayer $\mathrm{MoO}_{\mathrm{x}} / \mathrm{PEDOT}$ :PSS to improve the performance and stability of the solution processed perovskite solar cells. ${ }^{9}$ Chen et al. used thermally evaporated $\mathrm{MoO}_{\mathrm{x}}$ in the inverted structure of the perovskite solar cell achieving 13\% efficiency and good stability. ${ }^{10}$ These results suggest that $\mathrm{MoO}_{\mathrm{x}}$ is a promising material as an alternative HTM.

Different techniques have been used for the preparation of $\mathrm{MoO}_{\mathrm{x}}$ thin films with an amorphous and crystalline structure. Films can be deposited using solution-based methods and vacuum deposition techniques. The solution methods include spray pyrolysis, ${ }^{17}$ sol-gel process,${ }^{18}$ electrodeposition, and spin coating ${ }^{19}$ whereas the vacuum methods are thermal evaporation, ${ }^{20}$ sputtering, ${ }^{21}$ and electron beam evaporation (e-beam). ${ }^{22}$ Solution processing is usually easy and cheap; however, there is less control over the film properties, leading to poor reproducibility. Vacuum deposition however has good control over the film properties and reproducibility. Also, a wide range of experimental parameters are available which can tailor the structure, morphology, composition, and other properties of the films according to the required applications.

In this study, empirical simulation using the solar cell capacitance simulator software (SCAPS) was applied to investigate $\mathrm{MoO}_{\mathrm{x}}$ as an alternative HTM for perovskite solar cells. $\mathrm{MoO}_{\mathrm{x}}$ thin films deposited at different substrate 
temperatures by the electron beam evaporation technique were considered for the simulation. Helium Ion Microscopy (HIM) and Atomic Force Microscopy (AFM) were used to study the surface morphology of the films. The surface roughness was measured by AFM and confirmed using the stylus profilometer. The film thickness was measured by both stylus profilometer and ellipsometry. The chemical composition was investigated using X-Ray Photoelectron Spectroscopy (XPS), and the crystalline nature of the films was determined using Raman spectroscopy. The optical properties of the films were characterized using UV-Vis-NIR spectrometry. From these measurements, the thickness and bandgap energy $\left(\mathrm{E}_{\mathrm{g}}\right)$ of the $\mathrm{MoO}_{\mathrm{x}}$ thin films were used as input parameters in the empirical simulation analysis to study the films as an alternative HTM layer in both the inverted and regular structures of the PSC.

\section{EXPERIMENTAL}

\section{A. Thin film deposition}

$\mathrm{MoO}_{\mathrm{x}}$ thin films were deposited on a glass substrate using the electron beam evaporation technique (PVD 75 Kurt J. Lesker) from $\mathrm{MoO}_{3}$ pellets (99.9\% purity). The films were deposited at different substrate temperatures (room temperature, $100^{\circ} \mathrm{C}$ and $200^{\circ} \mathrm{C}$ ). For the films deposited at $100^{\circ} \mathrm{C}$ and $200^{\circ} \mathrm{C}$, the substrate was preheated to the desired temperature and maintained at that temperature throughout the deposition. Before each deposition, the glass was cleaned thoroughly with acetone, ethanol, and then dried with nitrogen gas. The chamber was evacuated to a base pressure of less than $1 \times 10^{-6}$ Torr. As expected, the pressure slightly increased to $4 \times 10^{-5}$ Torr during the film deposition due to the vapour of the $\mathrm{MoO}_{3}$. The films were deposited at a deposition rate of $1 \AA / \mathrm{s}$ as controlled by the quartz crystal monitor. All the films had a nominal thickness of $100 \mathrm{~nm}$. During deposition the substrate was continuously rotating at $10 \mathrm{rpm}$ in order to ensure uniform and homogenous coatings fully covering the substrate. After deposition, the samples were allowed to naturally cool in the vacuum chamber to less than $50^{\circ} \mathrm{C}$ before they were taken out of the chamber for characterization.

\section{B. Thin film characterization}

Various techniques were used to characterize the asdeposited $\mathrm{MoO}_{\mathrm{x}}$ thin films. The surface morphology of the films was characterized by Atomic Force Microscope (AFM) and Helium Ion Microscope (HIM). An NT-MDT Solver P47 scanning probe microscope (NT-MDT Co., Moscow, Russia) operated in the semi-contact mode with "Golden" Si cantilevers was used in the AFM measurement. The nominal tip diameter was $10 \mathrm{~nm}$. High resolution micrographs were obtained using Zeiss Orion HIM at $25 \mathrm{kV}$ with a $0.3 \mathrm{pA}$ blank current. HIM is found to be the preferred technique for characterizing the as-deposited $\mathrm{MoO}_{\mathrm{x}}$ thin films without using conductive coating. Any charging caused by the insulating properties of the films can be compensated using a flood gun having a beam of electrons which compensate for the accumulated ion beam charge. The thickness of the films was measured by the stylus profilometer and confirmed by ellipsometry. X-ray photoelectron spectroscopy was performed using a Kratos Axis Supra with aluminium $\mathrm{Al} \mathrm{K} \mathrm{K}_{\alpha}$ $\mathrm{X}$-ray radiation $(\mathrm{h} \nu=1486.7 \mathrm{eV})$. Wide survey scans were acquired using the analyzer pass energy of $160 \mathrm{eV}$, and high resolution scans of the $\mathrm{O} \mathrm{s}, \mathrm{C} 1 \mathrm{~s}$, and Mo $3 \mathrm{~d}$ regions were performed using a pass-energy of $20 \mathrm{eV}$ to better discriminate the sub-structure of the spectral lines. In all cases, the binding energy scale was corrected by a rigid shift to align the peak of the $\mathrm{C} 1 \mathrm{~s}$ core level to $284.8 \mathrm{eV}$, corresponding to adventitious carbon. Quantification was performed using the CasaXPS software version 2.3.17PR1.1, using the appropriate element sensitivity library for the Kratos instrument. Carbon present on the surface was assumed to be adventitious in nature, and as such a fraction of the measured oxygen signal was associated to the surface contamination, using the method of Payne et al. ${ }^{23}$ Mo 3d and O 1s spectra were fitted with a series of Voigt line shapes, using area constraints across Mo and $\mathrm{O}$ chemical states to enforce the expected 3:1 and 5:2 intensity ratios for Mo (VI) and Mo (V). However, the Mo (V) line shape is known to be somewhat more complicated than a simple Voigt function due to multiple splitting. ${ }^{24}$ We have found that our analysis using simple mathematical models is self-consistent. The mean ratio for the total O:Mo ratio determined from high resolution analysis yielded the same result as found using the total intensity of O:Mo from the survey spectrum.

The chemical structure and crystalline state of the $\mathrm{MoO}_{\mathrm{x}}$ films were studied using the Renishaw inVia Raman spectrometer. A Renishaw frequency doubled NdYAG laser excitation source of wavelength $532 \mathrm{~nm}$ was used. To avoid local heating of the samples, a low power of about $5 \mathrm{~mW}$ was applied to the samples. A Raman shift between the wavenumber 200 to $1200 \mathrm{~cm}^{-1}$ was measured. The transmittance of the $\mathrm{MoO}_{\mathrm{x}}$ films on the glass substrate was measured using the Cary 5000 UV-Vis-NIR spectrophotometer with a $150 \mathrm{~mm}$ integrating sphere. The measurements were performed in the wavelength range 300 to $2500 \mathrm{~nm}$ at a near-normal angle of incidence. The measured transmittance values were subtracted from the base (zero) signal. A Teflon coating was used as a $100 \%$ reference. From these measurements, the weighted solar transmittance for A.M. 1.5 and optical bandgap of the films were obtained.

\section{Simulation of perovskite solar cell}

The SCAPS simulator was used for the simulation of the perovskite solar cell device using $\mathrm{MoO}_{\mathrm{x}}$ as HTM. SCAPS software is developed at Electronics and Information Systems (ELIS), University of Gent, which is modelled under an AM 1.5 light spectrum. ${ }^{25}$ It is very well-known simulation software in thin film solar cells as well as solar cells that have a planar structure. ${ }^{26}$ In this work, a planar structure consisting of regular $\left(\mathrm{FTO} / \mathrm{TiO}_{2} / \mathrm{CH}_{3} \mathrm{NH}_{3} \mathrm{PbI}_{3} /\right.$ $\left.\mathrm{MoO}_{\mathrm{x}} / \mathrm{Au}\right)$ and inverted $\left(\mathrm{FTO} / \mathrm{MoO}_{\mathrm{x}} / \mathrm{CH}_{3} \mathrm{NH}_{3} \mathrm{PbI}_{3} / \mathrm{PCBM} /\right.$ $\mathrm{Au}$ ) configuration were used for the simulation of the perovskite solar cell. Input parameters used for the simulation of the device were obtained from experimental results of this work and literature as shown in Table I. Here, $\mathrm{N}_{\mathrm{A}}$ and $\mathrm{N}_{\mathrm{D}}$ 
TABLE I. Input parameters obtained from this experiment and various reference papers for SCAPS simulation of PSC using MoO as HTM. $^{29}$

\begin{tabular}{|c|c|c|c|c|c|c|}
\hline Parameters & FTO (TCO) & $\mathrm{TiO}_{2}$ & ${ }^{\mathrm{a}} \mathrm{IDL} 1$ & Perovskite & ${ }^{\mathrm{b}} \mathrm{IDL} 2$ & $\mathrm{MoO}_{\mathrm{x}}$ \\
\hline Thickness (nm) & 370 & 50 & 10 & 330 & 10 & ${ }^{\mathrm{c}} 50-250$ \\
\hline $\mathrm{N}_{\mathrm{A}}\left(\mathrm{cm}^{-3}\right)$ & $\ldots$ & $\ldots$ & $\ldots$ & $\ldots$ & $\ldots$ & $2 \times 10^{18}$ \\
\hline $\mathrm{N}_{\mathrm{D}}\left(\mathrm{cm}^{-3}\right)$ & $2 \times 10^{19}$ & $10^{16}$ & $10^{13}$ & $10^{13}$ & $10^{13}$ & $\ldots$ \\
\hline$\varepsilon_{\mathrm{r}}$ & 9 & 9 & 6.5 & 6.5 (Ref. 30) & 6.5 & 4.45 \\
\hline$\chi(\mathrm{eV})$ & 4 & 3.90 & 3.90 & 3.90 (Ref. 29) & 3.90 & $2.2($ Ref. 31) \\
\hline $\mathrm{E}_{\mathrm{g}}(\mathrm{eV})$ & 3.50 & 3.20 & 1.55 & 1.55 (Ref. 32) & 1.55 & $3.45-3.75\left({ }^{\mathrm{d}} \exp \right)$ \\
\hline$\mu_{\mathrm{n}} / \mu_{\mathrm{p}}\left(\mathrm{cm}^{2} / \mathrm{V} \mathrm{s}\right)$ & $20 / 10$ & $20 / 10$ & $2.0 / 2.0$ & $2.0 / 2.0$ (Ref. 33) & $2.0 / 2.0$ & $1.1 \times 10^{3}($ Ref. 34$)$ \\
\hline $\mathrm{N}_{\mathrm{t}}\left(\mathrm{cm}^{-3}\right)$ & $10^{15}$ & $10^{15}$ & $10^{17}$ & $2.5 \times 10^{13}$ & $10^{17}$ & $10^{15}$ \\
\hline
\end{tabular}

aIDL1: Interface Defect Layer between ETL/Perovskite.

${ }^{b}$ IDL2: Interface Defect Layer between Perovskite/HTL.

${ }^{c}$ This thickness range includes the experimental value of $\mathrm{MoO}_{\mathrm{x}}(100 \mathrm{~nm})$.

dexp: Experimental results of this work.

denote the acceptor and donor densities, $\varepsilon_{\mathrm{r}}$ is the relative permittivity, $\chi$ is the electron affinity, $\mathrm{E}_{\mathrm{g}}$ is the bandgap energy, $\mu_{\mathrm{n}}$ and $\mu_{\mathrm{p}}$ are mobility of electron and hole, and $\mathrm{N}_{\mathrm{t}}$ is the defect density. ${ }^{27,28}$ The other parameters not mentioned in the Table are the effective density of charge at the conduction band $\left(\mathrm{N}_{\mathrm{C}}\right)$ and at the valence band $\left(\mathrm{N}_{\mathrm{V}}\right)$, which have values of $2 \times 10^{18}$ and $1.8 \times 10^{19}$, respectively. ${ }^{28}$

\section{RESULTS AND DISCUSSIONS}

\section{A. Structural properties}

The Raman spectra of the $\mathrm{MoO}_{\mathrm{x}}$ thin films deposited at different substrate temperatures is shown in Fig. 1. Three sharp Raman peaks obtained at 665,820 , and $995 \mathrm{~cm}^{-1}$ belong to the orthorhombic $\alpha$-phase of molybdenum oxide. ${ }^{35}$ Such a phase is normally obtained after high temperature annealing $\left(450^{\circ} \mathrm{C}\right)$. The film deposited at room temperature has shown peaks of $\alpha$-phase with very weak Raman intensity which is the characteristics of amorphous films. ${ }^{36}$ The peak intensity, however, increases with increasing substrate temperature and this

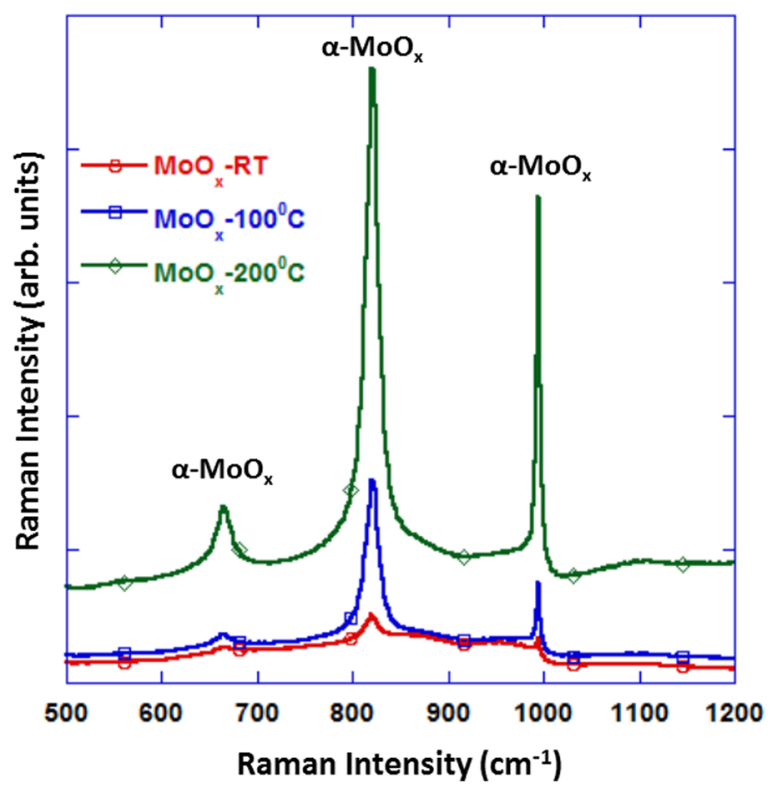

FIG. 1. Raman spectra of $\mathrm{MoO}_{\mathrm{x}}$ thin films deposited by e-beam evaporation at different substrate temperatures (RT, $100^{\circ} \mathrm{C}$ and $200^{\circ} \mathrm{C}$ ). In Refs. 35 and 36 , the peaks were assigned to the $\alpha$-phase of $\mathrm{MoO}_{3}$. shows that the films deposited at higher substrate temperatures are dominated by the crystalline properties. ${ }^{36}$ The Raman band at $995 \mathrm{~cm}^{-1}$ is assigned to the terminal oxygen $(\mathrm{Mo}=\mathrm{O})$ stretching mode, whereas the $820 \mathrm{~cm}^{-1}$ to the doubly connected bridge-oxygen $(\mathrm{Mo}-\mathrm{O}-\mathrm{Mo})$ stretching mode and the $665 \mathrm{~cm}^{-1}$ to the triply connected bridge-oxygen $\left(\mathrm{Mo}_{3}-\mathrm{O}\right)$ vibration. ${ }^{37}$ The peak at $820 \mathrm{~cm}^{-1}$ has high sharpness for the films deposited at $100^{\circ} \mathrm{C}$ and $200^{\circ} \mathrm{C}$ which indicates that the corresponding vibrational modes are due to the highly ordered structure. The corner-sharing chains of $\mathrm{MoO}_{6}$ octahedra may be visualized in the $\alpha$-phase which shares the edge with two similar chains to form the $\mathrm{MoO}_{3}$ stoichiometry. Each octahedron of $\mathrm{MoO}_{3}$ has one unshared oxygen atom, two oxygen atoms are common to two octahedra, and three oxygens are in part-shared edges and common to the three octahedra, ${ }^{36}$ which referred as the $\alpha$-phase. ${ }^{38}$

To observe the effect of substrate temperature on the chemical characteristics of $\mathrm{MoO}_{\mathrm{x}}$ thin films, XPS analysis was conducted. Figure 2 shows a series of survey and high resolution (Mo 3d, O 1s and C 1s) spectra of the $\mathrm{MoO}_{\mathrm{x}}$ thin films deposited at different substrate temperatures. The films produced at room temperature consist of pure $\mathrm{MoO}_{3}$, as they exhibit the oxygen to molybdenum ratio of 3:1. This implies that a pure stoichiometric film is deposited from the electron

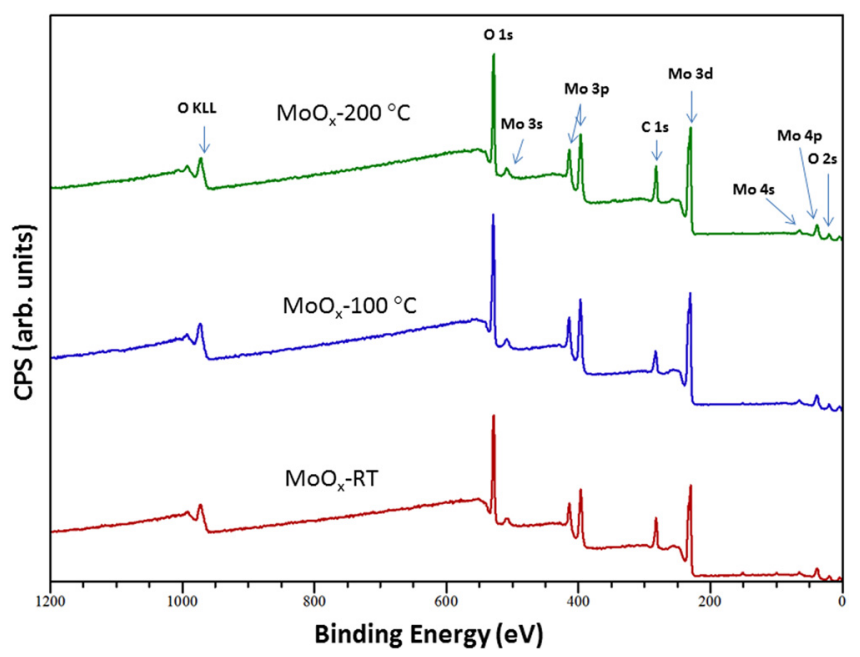

FIG. 2. XPS of $\mathrm{MoO}_{\mathrm{x}}$ thin films deposited by e-beam evaporation at different substrate temperatures (RT, $100^{\circ} \mathrm{C}$ and $200^{\circ} \mathrm{C}$ ). 
beam evaporator at room temperature. High resolution scans of the Mo 3d and $\mathrm{O} 1 \mathrm{~s}$ core level confirm this finding, where the Mo 3d doublet can be fitted with a single doublet pair with the expected $3: 2$ intensity ratio between the $3 \mathrm{~d}_{5 / 2}$ and $3 \mathrm{~d}_{3 / 2}$ states. By contrast, the films deposited at elevated temperatures $\left(100^{\circ} \mathrm{C}\right.$ and $\left.200^{\circ} \mathrm{C}\right)$ show a significant reduction of $\mathrm{Mo}(\mathrm{V})$ state, with films deposited at $100{ }^{\circ} \mathrm{C}$ containing $75 \%$ Mo (V) and films deposited at $200{ }^{\circ} \mathrm{C}$ containing $76 \%$ Mo (V) as shown in Fig. 3. This analysis points to an overall oxygen to molybdenum ratio of $2.7: 1$ for the sample deposited at $200{ }^{\circ} \mathrm{C}$.

The high resolution Mo $3 \mathrm{~d}$ and $\mathrm{O}$ 1s scans in Fig. 3 are fitted based on an assumed 5:2 and 3:1 oxygen weighting of the Mo (V) and Mo (VI) components, respectively. The spectral weight of oxygen was adjusted for the presence of C-Ox species in adventitious carbon, ${ }^{23}$ as well as ascribing high-binding energy spectral weight to adsorbed water. As explained by Bulpett et al., the conduction band of $\mathrm{MoO}_{3}$ consists of empty $4 \mathrm{~d}$ and $5 \mathrm{~s}$ states whereas the valence band consists of oxygen $2 p$ state. At higher substrate temperature, the transition from oxygen $2 \mathrm{p}$ to an empty $\mathrm{Mo}^{6+} 4 \mathrm{~d}$ level will give rise to the incorporation of lower valency $\mathrm{Mo}^{5+}$ ion in the lattice. ${ }^{39}$

\section{B. Morphological properties}

Figure 4 shows the surface morphology of the $\mathrm{MoO}_{\mathrm{x}}$ thin films deposited at room temperature, $100^{\circ} \mathrm{C}$ and at $200^{\circ} \mathrm{C}$ characterized using HIM [Figs. 4(a)-4(c)] and AFM [Figs. 4(d)-4(f)]. Both films are homogenous with no cracks or pits and have smooth surface morphology covering the substrate uniformly as observed from the HIM micrographs in Figs. 4(a)-4(c). There is usually an increase in grain size with increasing deposition temperature, ${ }^{36}$ which is not obvious in the HIM and AFM images of this work. However, the surface roughness of the films slightly decreases with increasing deposition temperature as observed from the AFM images in Figs. 4(d)-4(f) and Table II. These surface roughness values were confirmed by the stylus profilometer and AFM.

\section{Optical properties}

Figure 5(a) shows the spectral transmittance of the $100 \mathrm{~nm} \mathrm{MoO}$ films deposited at different substrate temperatures. The films are highly transparent in the visible and nearinfrared wavelength region and their transmittance sharply dropped in the ultraviolet wavelength. With increasing
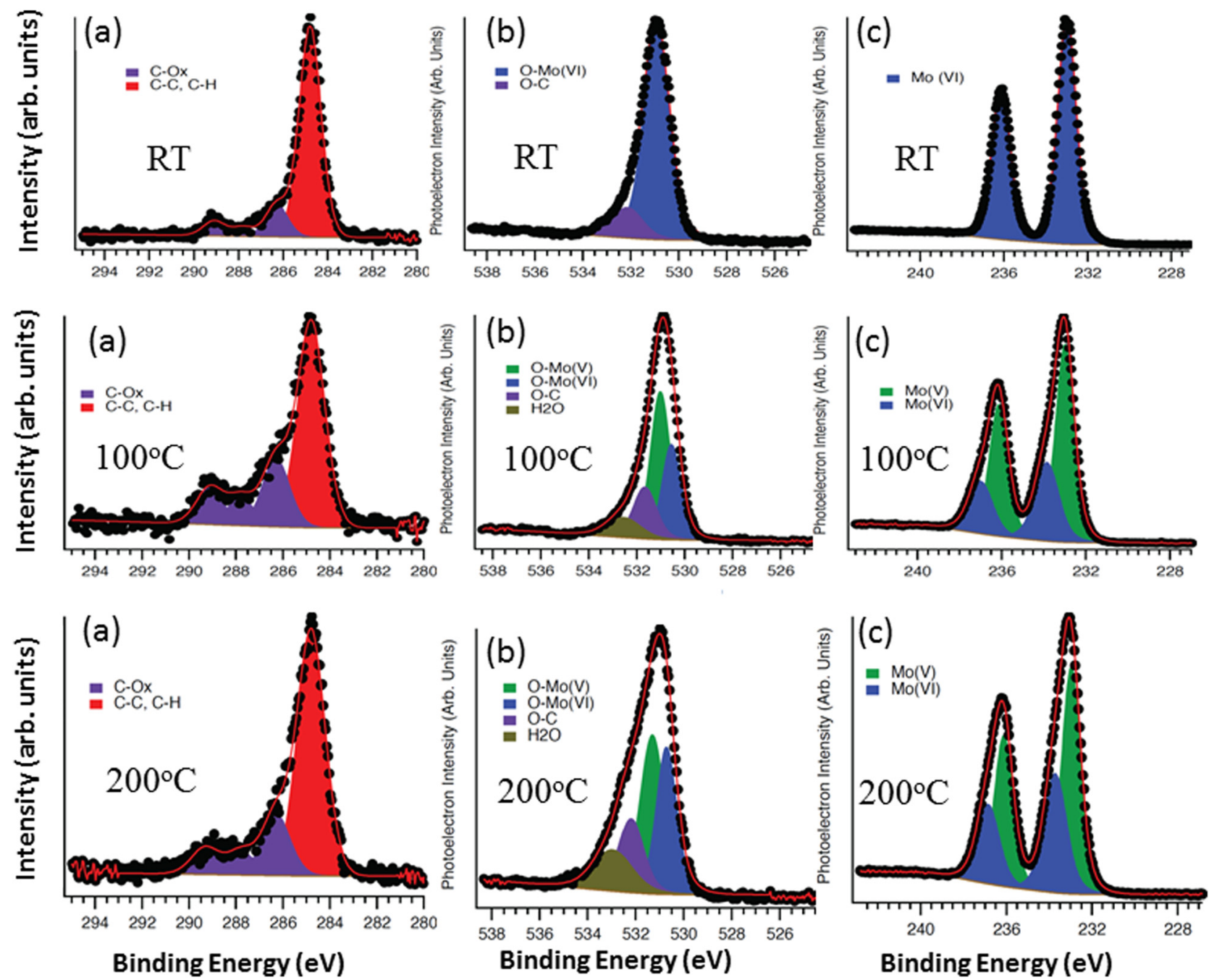

FIG. 3. XPS spectra of $\mathrm{MoO}_{\mathrm{x}}$ thin films at different substrate temperatures showing high resolution scans of (a) C 1s, (b) O 1s, and (c) Mo 3d core levels with synthetic fits to the spectral envelopes. 

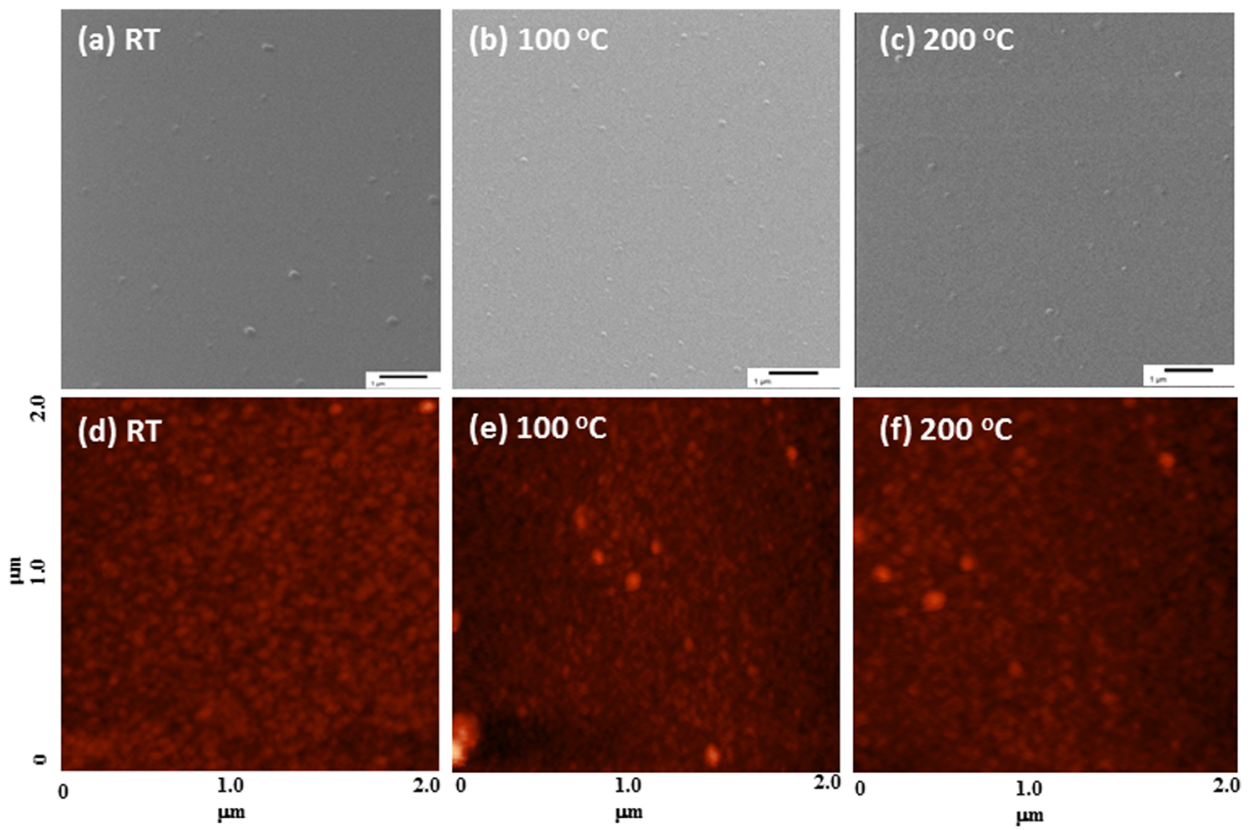

FIG. 4. Micrograph of $\mathrm{MoO}_{\mathrm{x}}$ thin films deposited at room temperature (a), (d), $100^{\circ} \mathrm{C}$ (b), (e), and $200^{\circ} \mathrm{C}$ (c), (f). (a), (b), (c) are HIM images having a scale bar of $1 \mu \mathrm{m}$ and (d), (e), (f) are AFM images scanned over $2 \mu \mathrm{m} \times 2 \mu \mathrm{m}$.
TABLE II. Transmittance, atomic ratio of O:Mo, surface roughness, and bandgap energy of $\mathrm{MoO}_{\mathrm{x}}$ thin films deposited at different substrate temperatures.

\begin{tabular}{lcccc}
\hline \hline $\begin{array}{l}\text { Substrate } \\
\text { temperature } \\
\left({ }^{\circ} \mathrm{C}\right)\end{array}$ & $\begin{array}{c}\text { Transmittance } \\
(\mathrm{T} \%)\end{array}$ & O:Mo ratio & $\begin{array}{c}\text { RMS surface } \\
\text { roughness } \\
(\mathrm{nm})\end{array}$ & $\begin{array}{c}\text { Bandgap } \\
\text { Energy E } \\
(\mathrm{eV})\end{array}$ \\
\hline $\mathrm{RT}$ & 84 & 2.96 & 2.0 & 3.75 \\
100 & 82 & 2.76 & 1.59 & 3.50 \\
200 & 81 & 2.69 & 1.50 & 3.45 \\
\hline \hline
\end{tabular}

deposition temperature, the absorption edge shifts towards the longer wavelength. From the Raman spectra, the film deposited at room temperature has amorphous behaviour and this property can also be observed from the optical spectra in Fig. 5(a) having low interference fringes. The strong coloration of the films deposited at high temperature is due to oxygen ion vacancies, which promotes the reduction of oxygen atoms in the oxide structure which is confirmed from the XPS data. ${ }^{40}$ The weighted optical transmittance of all the films in the solar wavelength is more than $80 \%$ as shown in Table II with slightly higher value observed from the amorphous film. This amorphous film has slightly higher transmittance in the infrared compared to the crystalline $\mathrm{MoO}_{\mathrm{x}}$ films. The interference fringes would also have effect on the variation in the weighted solar transmittance.

The bandgap energy $\left(\mathrm{E}_{\mathrm{g}}\right)$ of the $\mathrm{MoO}_{\mathrm{x}}$ films $(100 \mathrm{~nm})$ was calculated using the relation ${ }^{40}$

$$
(\alpha \mathrm{h} \nu)^{2}=\mathrm{A}\left(\mathrm{h} \nu-\mathrm{E}_{\mathrm{g}}\right)
$$

where $\alpha$ is the absorption coefficient, $\mathrm{A}$ is the band edge parameter, $h$ is the Plank constant, and $\nu$ is the frequency of light. The plot produced from this relation is known as the Tauc plot and gives a linear behaviour in the high energy region. The $E_{g}$ of the films is then calculated by fitting the linear region of the plot to zero. Figure 5(b) shows the $(\alpha \mathrm{h} \nu)$ vs photon energy $(\mathrm{h} \nu)$. The estimated $\mathrm{E}_{\mathrm{g}}$ value of $\mathrm{MoO}_{\mathrm{x}}$ deposited at room temperature is $3.75 \mathrm{eV}$ (see Table II). This value decreases to $3.45 \mathrm{eV}$ when the film was deposited at $200{ }^{\circ} \mathrm{C}$. The decrease in bandgap energy is attributed to the oxygen vacancies which enable to capture electrons and act as a donor centres. ${ }^{41}$ The deficiency of oxygen is confirmed by the XPS result which shows that the atomic percentage of
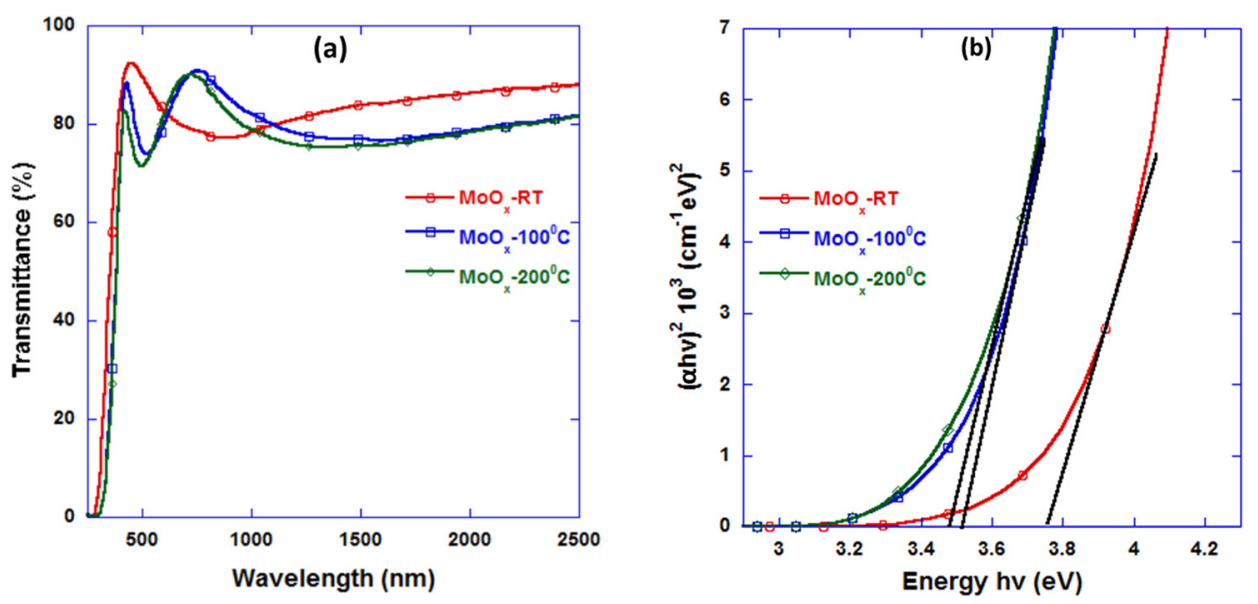

FIG. 5. (a) Transmittance spectra and (b) $(\alpha h v)^{2} v s h v$ plot of $100 \mathrm{~nm}$ thick $\mathrm{MoO}_{\mathrm{x}}$ thin films deposited at various substrate temperatures. 
(a)

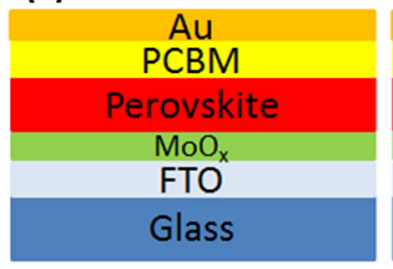

(b)

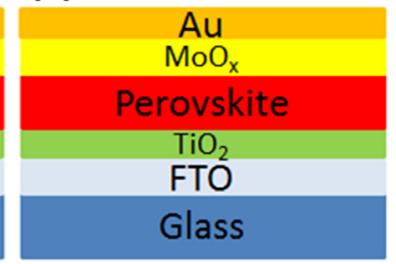

FIG. 6. Schematic diagram of (a) inverted structure and (b) regular structure of a perovskite solar cell used in SCAPS simulation.

oxygen is reduced with the increase in the substrate temperature (see Table II). The bandgap energy of $\mathrm{MoO}_{\mathrm{x}}$ obtained in this work (3.45-3.75 eV) are found to be within the values of e-beam deposited molybdenum oxide films reported in the literature $(3.1-3.7 \mathrm{eV}){ }^{42}$ These experimentally obtained $\mathrm{E}_{\mathrm{g}}$ values of $\mathrm{MoO}_{\mathrm{x}}$ for a $100 \mathrm{~nm}$ thick film are used in the SCAPS simulation to predict the efficiency of the regular and inverted structures of the PSC. In the simulation, the $\mathrm{MoO}_{\mathrm{x}}$ film thickness was varied between 50 and $250 \mathrm{~nm}$ that included the experiment film thickness in order to observe the effect of film thickness on the various parameters of the solar cells.

\section{Simulation of perovskite solar cell with $\mathrm{MoO}_{\mathrm{x}}$ as HTM}

Empirical simulation analysis using the SCAPS simulation software was performed to study the performance of perovskite solar cell with $\mathrm{MoO}_{\mathrm{x}}$ as an HTM layer. The schematic diagram of the inverted and regular structures used in the simulation is shown in Figs. 6(a) and 6(b), respectively. A typical perovskite solar cell configuration adopts a solid planar heterojunction $\mathrm{p}-\mathrm{i}-\mathrm{n}$ structure where the perovskite material in the regular structure is sandwiched between Electron Transport Layer (ETL) $\left(\mathrm{TiO}_{2}\right)$ and HTM $\left(\mathrm{MoO}_{\mathrm{x}}\right)$. In the regular structure, the HTM is applied on the top of the perovskite material; thus, deposition of $\mathrm{MoO}_{\mathrm{x}}$ at only room temperature is suitable as the perovskite material is sensitive to elevated temperature (more than $100^{\circ} \mathrm{C}$ ). In the inverted structure, the HTM $\left(\mathrm{MoO}_{\mathrm{x}}\right)$ is applied on the top of fluorine doped tin oxide (FTO) and PCBM is typically used as ETL and allows high substrate temperature deposition of the $\mathrm{MoO}_{\mathrm{x}}$ thin films. FTO coated glass is used as a transparent conductive oxide, and $\mathrm{Au}$ serves as a back metal contact. Thus, using the experimentally obtained bandgap energy $(3.75 \mathrm{eV})$ and film thickness $(100 \mathrm{~nm})$ of $\mathrm{MoO}_{\mathrm{x}}$, the solar cell efficiency for both the regular and inverted structures are found to be $18.21 \%$ to $17.85 \%$, respectively.

An optimum thickness of the HTM with full surface coverage is very important for the device performance. Figure 7 shows the effect of $\mathrm{MoO}_{\mathrm{x}}$ thickness on the open circuit voltage $\left(\mathrm{V}_{\mathrm{oc}}\right)$, short-circuit current density $\left(\mathrm{J}_{\mathrm{sc}}\right)$, recombination current density $\left(\mathrm{J}_{\mathrm{rec}}\right)$, fill factor $(\mathrm{FF})$, and efficiency for both the regular [Fig. 7(a)] and inverted [Fig. 7(b)] structures. As observed in the figure, the $\mathrm{J}_{\mathrm{sc}}$ slightly decreases with the increase in $\mathrm{HTM}\left(\mathrm{MoO}_{\mathrm{x}}\right)$ thickness whereas the $\mathrm{V}_{\mathrm{oc}}$ remains unchanged. This decrease in $\mathrm{J}_{\mathrm{sc}}$ can be linked to the increase in recombination current as shown in the Fig. 7(a). The total recombination current density $\left(\mathrm{J}_{\mathrm{rec}}\right)$ increases with the increase of HTM thickness which causes a reduction in $\mathrm{J}_{\mathrm{sc}}$ and overall efficiency of the solar cell. The same trend is followed in both regular and inverted structures. This increase in recombination current density is due to longer distance that photo-generated carriers should transport to be driven out, whereas their life-time and mobility are kept constant. So a minimum of $\mathrm{MoO}_{\mathrm{x}}$ layer thickness that gives full layer coverage to minimize recombination in the HTM layer is desirable. Also, in the inverted structure [Fig. 7(b)] where the light enters through the $\mathrm{MoO}_{\mathrm{x}}$ side, the FF decreased with the increase of $\mathrm{MoO}_{\mathrm{x}}$ thickness due the increase in recombination current density and an increase in light absorption. From the HIM images in Fig. 4, the $100 \mathrm{~nm}$ thick $\mathrm{MoO}_{\mathrm{x}}$ films deposited at different substrate temperatures have fully covered the substrate. By varying the $\mathrm{MoO}_{\mathrm{x}}$ layer thickness from 50 to $250 \mathrm{~nm}$ for the highest bandgap energy of $\mathrm{MoO}_{\mathrm{x}}$ obtained in Table II, the efficiency of the PSC only slightly decreases from $18.25 \%$ to $18.15 \%$ for the regular structure [Fig. 7(a)] and from $17.88 \%$ to $17.70 \%$ for the
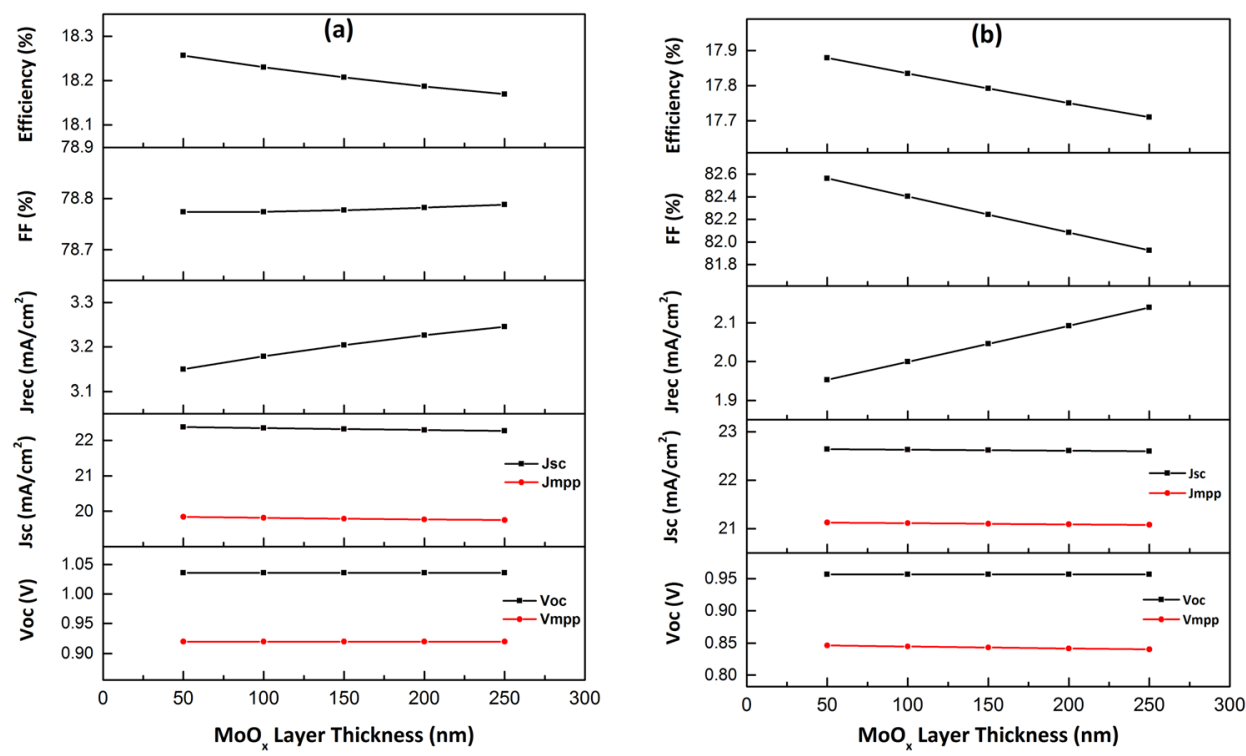

FIG. 7. Open circuit voltage $\left(\mathrm{V}_{\mathrm{oc}}\right)$, short-circuit current density $\left(\mathrm{J}_{\mathrm{sc}}\right)$, current recombination $\left(\mathrm{J}_{\mathrm{rec}}\right)$, fill factor $(\mathrm{FF})$, and efficiency of PSC as a function of $\mathrm{MoO}_{\mathrm{x}}$ layer thickness in (a) regular and (b) inverted PSC structure. The room temperature deposited bandgap energy $(3.75 \mathrm{eV})$ of $\mathrm{MoO}_{\mathrm{x}}$ films is considered. 

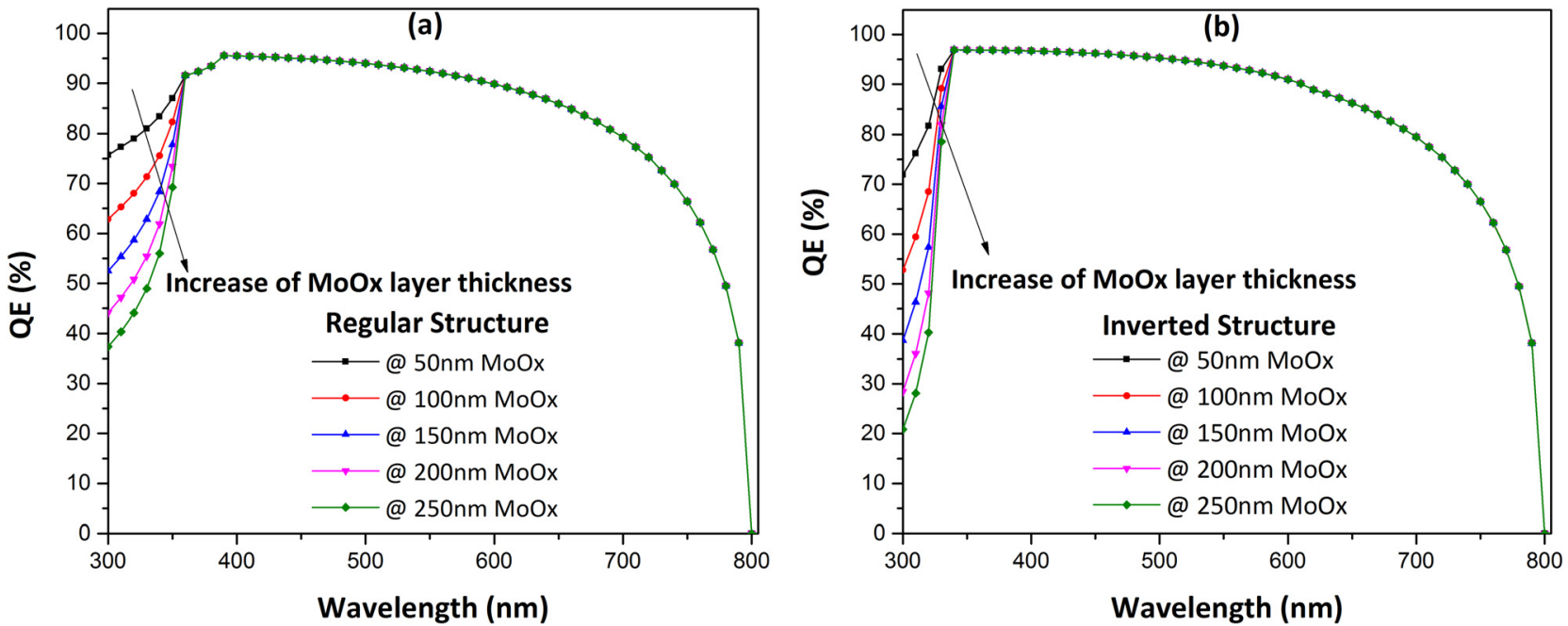

FIG. 8. Quantum efficiency of Perovskite solar cell using $\mathrm{MoO}_{\mathrm{x}}$ films with different thicknesses in (a) the regular structure and (b) the inverted structure. The room temperature deposited bandgap energy $(3.75 \mathrm{eV})$ of $\mathrm{MoO}_{\mathrm{x}}$ films is considered.

inverted structure [Fig. 7(b)]. The best cells with $50 \mathrm{~nm}$ thicknesses have shown high $\mathrm{V}_{\mathrm{oc}}$ and $\mathrm{J}_{\mathrm{sc}}$ values of $1.03 \mathrm{~V}$ and $22.3 \mathrm{~mA} / \mathrm{cm}^{2}$ for the regular structure, and $0.97 \mathrm{~V}$ and $22.7 \mathrm{~mA} / \mathrm{cm}^{2}$ for the inverted structure with a fill factor of 78.7 and 82.5 , respectively.

The quantum efficiency $(\mathrm{QE})$ is one of the important parameters that describe the quality of light absorption, charge transfer, and collection of a solar cell. As shown in Fig. 8, the QE for the (a) regular and (b) inverted structures $\left(\mathrm{E}_{\mathrm{g}}=3.75 \mathrm{eV}\right)$ decreases with the increase of HTM thickness in the wavelength region below $400 \mathrm{~nm}$ and this is more prominent in the regular structure of the solar cell. The decrease in $\mathrm{QE}$ at the lower wavelength can be due to the recombination in the $\mathrm{MoO}_{\mathrm{x}}$ layer and/or the light absorption of $\mathrm{MoO}_{\mathrm{x}}$ layer. The carriers which are generated by the high energy photons ( $>$ bandgap energy of $\mathrm{MoO}_{\mathrm{x}}$ ) do not contribute to the quantum efficiency because they cannot reach the back contact of the inverted structure PSC due to their limited life time and mobility leading to enhanced recombination in the $\mathrm{MoO}_{\mathrm{x}}$ layer. Smaller bandgap of $\mathrm{MoO}_{\mathrm{x}}$ means the photons at wavelength less than $400 \mathrm{~nm}$ can be absorbed by the $\mathrm{MoO}_{\mathrm{x}}$ layer, which in turn reduces the effective light absorption of the perovskite light absorber and thus the QE. The higher the $\mathrm{MoO}_{\mathrm{x}}$ thickness, the higher is the light absorption by the HTM of the inverted structure and the lower the QE.

As discussed before, the experimental results have confirmed that the increase in substrate temperature causes an increase in the crystallinity, a decrease in the bandgap energy along with the overall oxygen to molybdenum ratio and surface roughness of the $\mathrm{MoO}_{\mathrm{x}}$ thin film. Thus, the effect of $\mathrm{MoO}_{\mathrm{x}}$ bandgap energy on the PSC performance for the inverted structure has been investigated using SCAPS simulation. As shown in Fig. 9(a) for the $100 \mathrm{~nm}$ layer of $\mathrm{MoO}_{\mathrm{x}}$, the $\mathrm{J}_{\mathrm{sc}}$ increases from $22.3 \mathrm{~mA} / \mathrm{cm}^{2}$ to $22.6 \mathrm{~mA} / \mathrm{cm}^{2}$, whereas the $\mathrm{V}_{\mathrm{oc}}$ remains constant with increasing $\mathrm{MoO}_{\mathrm{x}}$ bandgap. The recombination current density decreases with the increase of bandgap energy. The increase in $\mathrm{J}_{\mathrm{sc}}$ governs an overall increase in the efficiency of the simulated PSC device to $17.85 \%$ as shown in Fig. 9(a). From the above analysis,

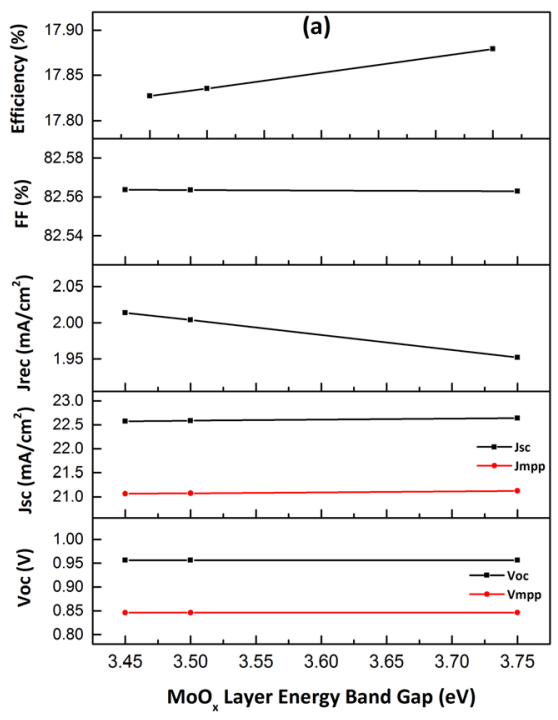

(a)

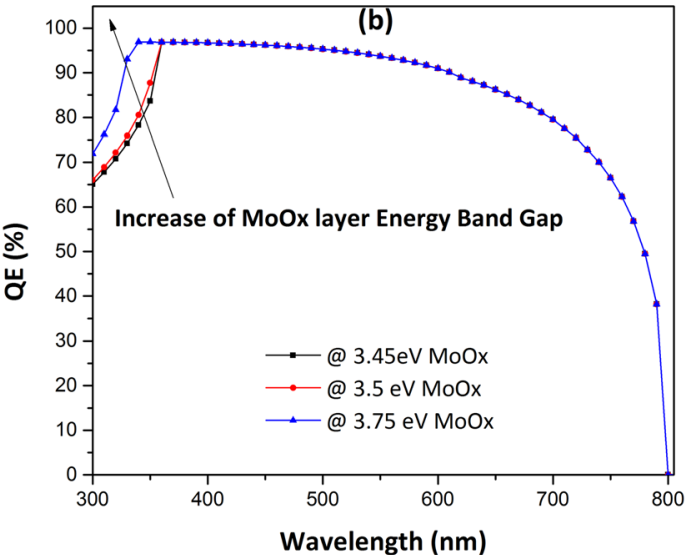

(b)
FIG. 9. (a) Open circuit voltage $\left(\mathrm{V}_{\mathrm{oc}}\right)$, short-circuit current density $\left(\mathrm{J}_{\mathrm{sc}}\right)$, current recombination $\left(\mathrm{J}_{\mathrm{rec}}\right)$, fill factor (FF), efficiency, and (b) quantum efficiency of PSC as a function of $\mathrm{MoO}_{x}$ bandgap energy in the inverted structure for a film thickness of $100 \mathrm{~nm}$. 
deposition of $\mathrm{MoO}_{\mathrm{x}}$ films at higher substrate temperature causes a reduction in the bandgap energy which reduces the simulated $\mathrm{J}_{\mathrm{sc}}$. Variation in QE with different $\mathrm{MoO}_{\mathrm{x}}$ bandgap energies $\left(100 \mathrm{~nm}\right.$ layer of $\left.\mathrm{MoO}_{\mathrm{x}}\right)$ is shown in Fig. 9(b). An increase in $\mathrm{QE}$ with the increase of the $\mathrm{MoO}_{\mathrm{x}}$ bandgap energy is observed at the lower wavelength region. However, with increasing deposition temperature, an increase in both crystallinity and defect density of the film and a reduction in surface roughness were observed. These properties which are useful for enhancing the performance of the solar cell were not considering in the SCAPS simulation.

As shown in the simulated results, the variation in bandgap energy of $\mathrm{MoO}_{\mathrm{x}}$ as HTM only slightly affects the efficiency of the PSC. However, as observed in the experiment, deposition of $\mathrm{MoO}_{\mathrm{x}}$ thin films at higher substrate temperature (e.g., $200^{\circ} \mathrm{C}$ ) gives rise to oxygen deficiency and enhanced crystallinity of the films which would be expected to improve the performance and stability of the PSC. ${ }^{43}$ From the calculation, a thinner $\mathrm{MoO}_{\mathrm{x}}$ film of about $50 \mathrm{~nm}$ thick that can completely cover the surface of the substrate is found to be beneficial for enhanced QE. Using these conditions, the performance of the PSC was determined as shown in Fig. 10 with optimum efficiency of $17.82 \%$ and high QE.

\section{CONCLUSION}

SCAPS simulation software was used to determine $\mathrm{MoO}_{\mathrm{x}}$ as an alternative HTM in perovskite solar cells. The HTM layer thickness and bandgap energy obtained experimentally were used to study the device performance. Empirical simulation results indicate that a larger HTM thickness gives a lower efficiency due to higher recombination current $\left(\mathrm{J}_{\text {rec }}\right)$, whereas the bandgap energy has a slight effect on the efficiency of the PSC. Using the properties of electron beam evaporated $\mathrm{MoO}_{\mathrm{x}}$ film deposited at room temperature, the modelling shows an efficiency of $18.25 \%$ for the regular structure and $17.88 \%$ for the inverted structure. The $\mathrm{MoO}_{\mathrm{x}}$ deposited at higher substrate temperature $\left(200^{\circ} \mathrm{C}\right)$ is suitable for the inverted structure of PSC with promising efficiency of $17.82 \%$. The overall simulated results suggest that

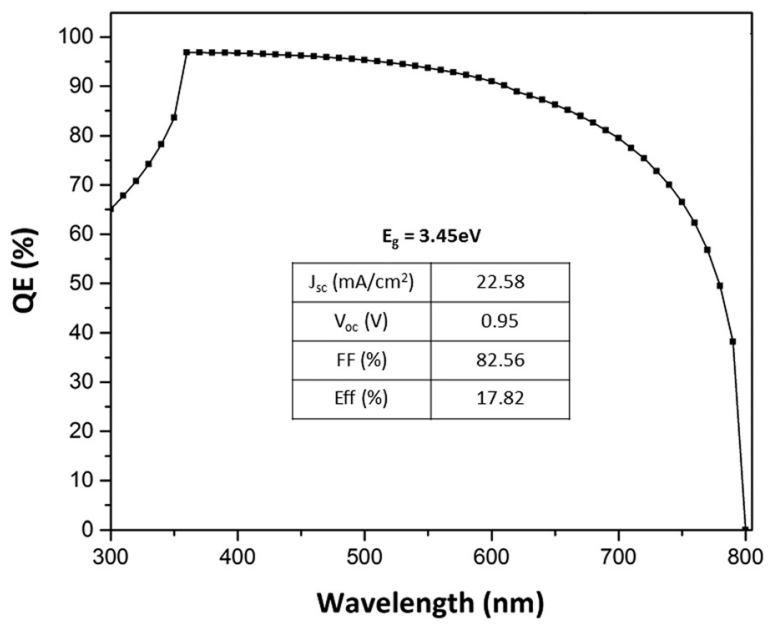

FIG. 10. Quantum efficiency (QE) of PSC using $\mathrm{MoO}_{\mathrm{x}}$ as $\mathrm{HTM}$ in the inverted structure of PSC. The inset shows the optimized efficiency of the PSC in the inverted structure using a film thickness of $50 \mathrm{~nm}$. the $\mathrm{MoO}_{\mathrm{x}}$ thin film is a potential hole transport inorganic material in the perovskite solar cell and can replace the organic hole transport materials with improved performance, stability, and lower cost. Experimental results of the $\mathrm{MoO}_{\mathrm{x}}$ films indicated a reduction in bandgap energy, oxygen composition, and surface roughness but enhanced crystallinity with increasing substrate temperature. Device fabrication using $\mathrm{MoO}_{\mathrm{x}}$ as HTM is needed to examine the effect of these parameters with the change of substrate temperature on the performance of perovskite solar cells.

\section{ACKNOWLEDGMENTS}

The first author is indebted for QUTPRA scholarship and financial support. H.W. acknowledges the financial support by the Australian Research Council (ARC) Future Fellowship (FT120100674) and the Queensland government (Q-CAS). This research was mainly done at the Institute for Future Environments (IFE) Central Analytical Research Facility (CARF) at QUT. Access to CARF is supported by generous funding from the Science and Engineering Faculty (QUT). We also thank Dr. Barry Wood (University of Queensland, Australia) for the XPS data acquisition and Mr. Akshay Prakash for contributing to the experimental data.

${ }^{1}$ A. Kojima, K. Teshima, Y. Shirai, and T. Miyasaka, J. Am. Chem. Soc. 131, 6050 (2009).

${ }^{2}$ W. S. Yang, J. H. Noh, N. J. Jeon, Y. C. Kim, S. Ryu, J. Seo, and S. I. Seok, Science 348(6240), 1234 (2015).

${ }^{3}$ N. D. Pham, V. T. Tiong, P. Chen, L. Wang, G. J. Wilson, J. Bell, and H. Wang, J. Mater. Chem. A 5(10), 5195 (2017).

${ }^{4}$ W. Chen, Y. Wu, Y. Yue, J. Liu, W. Zhang, X. Yang, H. Chen, E. Bi, I. Ashraful, M. Grätzel, and L. Han, Science 350(6263), 944 (2015).

${ }^{5}$ Y. Shao, Z. Xiao, C. Bi, Y. Yuan, and J. Huang, Nat. Commun. 5, 5784 (2014).

${ }^{6}$ L.-M. Chen, Z. Hong, G. Li, and Y. Yang, Adv. Mater. 21(14-15), 1434 (2009).

${ }^{7}$ D. Wang, M. Wright, N. K. Elumalai, and A. Uddin, Sol. Energy Mater. Sol. Cells 147, 255 (2016).

${ }^{8}$ S. S. Sunu, E. Prabhu, V. Jayaraman, K. I. Gnanasekar, and T. Gnanasekaran, Sens. Actuators, B 94(2), 189 (2003).

${ }^{9}$ F. Hou, Z. Su, F. Jin, X. Yan, L. Wang, H. Zhao, J. Zhu, B. Chu, and W. Li, Nanoscale 7(21), 9427 (2015).

${ }^{10}$ Z.-L. Tseng, L.-C. Chen, C.-H. Chiang, S.-H. Chang, C.-C. Chen, and C.G. Wu, Sol. Energy 139, 484 (2016).

${ }^{11}$ J. H. Kim, P. W. Liang, S. T. Williams, N. Cho, C. C. Chueh, M. S. Glaz, D. S. Ginger, and A. K. Jen, Adv. Mater. 27(4), 695 (2015).

${ }^{12}$ J. You, L. Meng, T. B. Song, T. F. Guo, Y. M. Yang, W. H. Chang, Z. Hong, H. Chen, H. Zhou, Q. Chen, Y. Liu, N. De Marco, and Y. Yang, Nat. Nanotechnol. 11(1), 75 (2016).

${ }^{13}$ I. A. de Castro, R. S. Datta, J. Z. Ou, A. Castellanos-Gomez, S. Sriram, T. Daeneke, and K. Kalantar-Zadeh, "Molybdenum oxides - from fundamentals to functionality," Adv. Mater. (published online 2017).

${ }^{14}$ H. Choi, J. H. Heo, S. Ha, B. W. Kwon, S. P. Yoon, J. Han, W.-S. Kim, S. H. Im, and J. Kim, Chem. Eng. J. 310(1), 179 (2017).

${ }^{15}$ C. Battaglia, X. Yin, M. Zheng, I. D. Sharp, T. Chen, S. McDonnell, A. Azcatl, C. Carraro, B. Ma, R. Maboudian, R. M. Wallace, and A. Javey, Nano Lett. 14(2), 967 (2014).

${ }^{16}$ M. Xiao, M. Gao, F. Huang, A. R. Pascoe, T. Qin, Y.-B. Cheng, U. Bach, and L. Spiccia, ChemNanoMat 2(3), 182 (2016).

${ }^{17}$ P. R. Patil and P. S. Patil, Thin Solid Films 382(1-2), 13 (2001).

${ }^{18}$ A. K. Prasad, D. J. Kubinski, and P. I. Gouma, Sens. Actuators, B 93(1-3), 25 (2003)

${ }^{19}$ R. S. Patil, M. D. Uplane, and P. S. Patil, Appl. Surf. Sci. 252(23), 8050 (2006).

${ }^{20}$ K. Srinivasa Rao, K. V. Madhuri, S. Uthanna, O. M. Hussain, and C. Julien, Mater. Sci. Eng., B 100(1), 79 (2003). 
${ }^{21}$ C. Imawan, H. Steffes, F. Solzbacher, and E. Obermeier, Sens. Actuators, B 78(1-3), 119 (2001).

${ }^{22}$ R. Sivakumar, R. Gopalakrishnan, M. Jayachandran, and C. Sanjeeviraja, Curr. Appl. Phys. 7(1), 51 (2007).

${ }^{23}$ B. P. Payne, M. C. Biesinger, and N. S. McIntyre, J. Electron Spectrosc. Relat. Phenom. 184(1-2), 29 (2011).

${ }^{24}$ J. Baltrusaitis, B. Mendoza-Sanchez, V. Fernandez, R. Veenstra, N. Dukstiene, A. Roberts, and N. Fairley, Appl. Surf. Sci. 326, 151 (2015).

${ }^{25}$ P. Nollet, M. Burgelman, and S. Degrave, Thin Solid Films 361-362, 293 (2000).

${ }^{26}$ N. Khoshsirat, N. Amziah, M. Yunus, M. N. Hamidon, S. Shafie, and N. Amin, paper presented at the 2013 IEEE International Conference on Circuits and Systems (ICCAS), 2013.

${ }^{27}$ N. Khoshsirat, N. Amziah, M. Yunus, M. N. Hamidon, S. Shafie, and N. Amin, Pertanika J. Sci. Technol. 23(2), 241 (2015), ISSN: 0128-7680.

${ }^{28}$ T. Minemoto and M. Murata, Curr. Appl. Phys. 14(11), 1428 (2014).

${ }^{29}$ T. Minemoto and M. Murata, J. Appl. Phys. 116(5), 054505 (2014).

${ }^{30}$ M. Liu, M. B. Johnston, and H. J. Snaith, Nature 501(7467), 395 (2013).

${ }^{31}$ C.-W. Chu, S.-H. Li, C.-W. Chen, V. Shrotriya, and Y. Yang, Appl. Phys. Lett. 87(19), 193508 (2005).

${ }^{32}$ J. H. Noh, S. H. Im, J. H. Heo, T. N. Mandal, and S. I. Seok, Nano Lett. 13(4), 1764 (2013).
${ }^{33}$ M. M. Lee, J. Teuscher, T. Miyasaka, T. N. Murakami, and H. J. Snaith, Science 338, 643 (2012).

${ }^{34}$ S. Balendhran, J. Deng, J. Z. Ou, S. Walia, J. Scott, J. Tang, K. L. Wang, M. R. Field, S. Russo, S. Zhuiykov, M. S. Strano, N. Medhekar, S. Sriram, M. Bhaskaran, and K. Kalantar-zadeh, Adv. Mater. 25(1), 109 (2013).

${ }^{35}$ M. Dieterle, G. Weinberg, and G. Mestl, Phys. Chem. Chem. Phys. 4(5), 812 (2002).

${ }^{36}$ R. K. Sharma and G. B. Reddy, J. Alloys Compd. 598, 177 (2014).

${ }^{37}$ K. Ajito, L. A. Nagahara, D. A. Tryk, K. Hashimoto, and A. Fujishima, J. Phys. Chem. 99, 16383 (1995).

${ }^{38}$ A. Magnéli, J. Inorg. Nucl. Chem. 2(5), 330 (1956).

${ }^{39}$ M. Anwar, C. A. Hogarth, and R. Bulpett, J. Mater. Sci. 24, 3087 (1989).

${ }^{40}$ S.-Y. Lin, Y.-C. Chen, C.-M. Wang, P.-T. Hsieh, and S.-C. Shih, Appl. Surf. Sci. 255(6), 3868 (2009).

${ }^{41}$ A. Bouzidi, N. Benramdane, H. Tabet-Derraz, C. Mathieu, B. Khelifa, and R. Desfeux, Mater. Sci. Eng., B 97(1), 5 (2003).

${ }^{42}$ M. Yahaya, Solid State Ionics 112, 421-423 (1998).

${ }^{43}$ Y. Li, J. K. Cooper, W. Liu, C. M. Sutter-Fella, M. Amani, J. W. Beeman, A. Javey, J. W. Ager, Y. Liu, F. M. Toma, and I. D. Sharp, Nat. Commun. 7, 12446 (2016). 